\title{
Substance P Weights Striatal Dopamine Transmission Differently within the Striosome-Matrix Axis
}

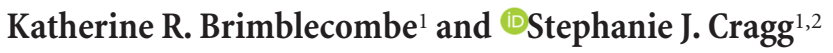 \\ 'Department of Physiology, Anatomy and Genetics and 20xford Parkinson's Disease Centre, University of Oxford, OX1 3PT, United Kingdom
}

The mammalian striatum has a topographical organization of input- output connectivity, but a complex internal, nonlaminar neuronal architecture comprising projection neurons of two types interspersed among multiple interneuron types and potential local neuromodulators. From this cellular melange arises a biochemical compartmentalization of areas termed striosomes and extrastriosomal matrix. The functions of these compartments are poorly understood but might confer distinct features to striatal signal processing and be discretely governed. Dopamine transmission occurs throughout striosomes and matrix, and is reported to be modulated by the striosomally enriched neuromodulator substance P. However, reported effects are conflicting, ranging from facilitation to inhibition. We addressed whether dopamine transmission is modulated differently in striosome-matrix compartments by substance $P$.

We paired detection of evoked dopamine release at carbon-fiber microelectrodes in mouse striatal slices with subsequent identification of the location of recording sites with respect to $\mu$-opioid receptor-rich striosomes. Substance $P$ had bidirectional effects on dopamine release that varied between recording sites and were prevented by inhibition of neurokinin-1 receptors. The direction of modulation was determined by location within the striosomal-matrix axis: dopamine release was boosted in striosome centers, diminished in striosomal-matrix border regions, and unaffected in the matrix. In turn, this different weighting of dopamine transmission by substance P modified the apparent center-surround contrast of striosomal dopamine signals. These data reveal that dopamine transmission can be differentially modulated within the striosomal-matrix axis, and furthermore, indicate a functionally distinct zone at the striosomematrix interface, which may have key impacts on striatal integration.

Key words: dopamine; NK1 receptors; striatum; striosomes; substance P; voltammetry

\section{Introduction}

The mammalian striatum is critical to the control of our voluntary movements, reinforcement, and motor learning. A network of interneurons and neuromodulators, including dopamine (DA) released from mesostriatal DA neurons, regulates the balance of outputs from two types of spiny projection neurons. The further differentiation of striatum into reticular patches called striosomes within the extrastriosomal matrix has long been known, and these compartments are developmentally, anatomically, and biochemically distinct (Graybiel and Ragsdale, 1978; Bolam et al., 1988; Gerfen, 1992; Crittenden and Graybiel, 2011). Surprisingly little, however, has been clarified about their differential function.

Anatomically, striosomes and matrix can be partially distinguished by their inputs and outputs. Inputs to striosomes versus

\footnotetext{
Received March 6, 2015; revised April 23, 2015; accepted April 27, 2015.

Author contributions: K.R.B. and S.J.C. designed research; K.R.B. performed research; K.R.B. analyzed data; K.R. B. and S.J.C. wrote the paper.

This work is funded by Parkinson's UK (Grant H-1003) and the Medical Research Council UK (MR/K013866/1). The authors declare no competing financial interests.

This article is freely available online through the J Neurosci Author Open Choice option.

Correspondence should be addressed to Stephanie J. Cragg, Department of Physiology, Anatomy and Genetics, Sherrington Building, University of 0xford, 0X1 3PT UK. E-mail:Stephanie.cragg@dpag.ox.ac.uk.

DOI:10.1523/JNEUROSCI.0870-15.2015

Copyright $\odot 2015$ Brimblecombe and Cragg

This is an Open Access article distributed under the terms of the Creative Commons Attribution License Creative Commons Attribution 4.0 International, which permits unrestricted use, distribution and reproduction in any medium provided that the original work is properly attributed.
}

matrix from cortex are predominantly from limbic versus motor areas, respectively (Gerfen, 1984; Crittenden and Graybiel, 2011). Dopaminergic inputs innervate both types of compartments but individual branches of axonal arbors tend to innervate one compartment type, with ventral tier substantia nigra (SN) neurons showing greater preference for striosomes than dorsal tier (Gerfen et al., 1987; Matsuda et al., 2009). In outputs, striosomes are relatively enriched in the DA D1 receptor-expressing, "direct" projecting subtype of medium spiny projection neurons (MSNs), although D1 MSNs are not restricted to striosomes (Johnston et al., 1990; Fujiyama et al., 2011). Only striosomal MSNs innervate SN DA neurons (Gerfen, 1984; Watabe-Uchida et al., 2012). Striatal neurons tend to be compartmentally confined, although some interneurons (cholinergic and somatostatin/nitric oxide synthase/neuropeptide-Y expressing) are located at, and across, compartment boundaries (Graybiel et al., 1986; Kubota and Kawaguchi, 1993). Biochemically, striosomes and matrix can be distinguished by numerous molecules, which in adulthood include higher expression in striosomes of substance P (SP), $\mu$-opioid receptors (MORs), and in matrix of calbindin-D28k and acetylcholinesterase (for review, see Crittenden and Graybiel, 2011). A further ring-like "annulus" or "striocapsular" region surrounding striosomes has been proposed based on metenkephalin enrichment and, at least in primates, by overlap of SP-rich fibers with receptors (Graybiel and Ragsdale, 1978; Gerfen et al., 1985; Jakab et al., 1996; Holt et al., 1997). 
The physiological functions conferred by striosome-matrix compartmentalization are poorly understood. The anatomical and biochemical differences of striosomes and matrix could be expected to support discrete control of function within each compartment. Indeed, MORs inhibit GABA transmission in striosomes but not matrix (Miura et al., 2007). SP is a key candidate neuromodulator for striosome-matrix compartmentalization of function. SP is released by D1-MSNs (Gerfen, 1992; Blomeley et al., 2009), is striosomally enriched (Graybiel et al., 1981; Bolam et al., 1988), and there are contradictory reports about its effects on DA transmission, which can be facilitatory (Starr, 1982; Petit and Glowinski, 1986; Tremblay et al., 1992), inhibitory (Starr, 1982; Gygi et al., 1993), or none (Boix et al., 1992; Guzman et al., 1993). Here, we investigated whether SP modulates DA transmission in a striosomematrix compartment-specific manner, and provide key evidence that striosomes and matrix offer differential control of striatal function.

\section{Materials and Methods}

Slice preparation and fast-scan cyclic voltammetry. Coronal striatal slices, $300 \mu \mathrm{m}$ thick, were prepared as previously (Threlfell et al., 2012; Brimblecombe et al., 2015) from male adult C57B6/J mice (Charles River), from a rostral region of the striatum $(\sim 1-1.3 \mathrm{~mm}$ rostral to bregma) that is striosome rich (Desban et al., 1993). All procedures were performed in accordance with the UK Animals (Scientific Procedures) Act 1986.

Extracellular dopamine concentration $\left([\mathrm{DA}]_{\mathrm{o}}\right)$ was monitored at $32^{\circ} \mathrm{C}$ with 7-8 $\mu \mathrm{m}$ carbon-fiber microelectrodes (CFMs) (tip length $\sim 50-100$ $\mu \mathrm{m}$ ) and a Millar voltammeter (Julian Millar, Barts and the London School of Medicine and Dentistry, UK) as described previously (Threlfell et al., 2012; Brimblecombe et al., 2015). In brief, the scanning voltage was a triangular waveform $(-0.7$ to $+1.3 \mathrm{~V} \mathrm{vs} \mathrm{Ag} / \mathrm{AgCl})$ at a scan rate of 800 $\mathrm{V} / \mathrm{s}$ and frequency of $8 \mathrm{~Hz}$. Currents were attributable to DA by potentials for peak oxidation and reduction currents $(+500 / 600$ and $-250 \mathrm{mV}$, respectively). Electrodes were calibrated post hoc with $2 \mu \mathrm{M}$ DA in experimental media.

DA release was evoked by a local bipolar concentric Pt/Ir electrode ( 25 $\mu \mathrm{m}$ diameter; FHC) placed $\sim 100 \mu \mathrm{m}$ away as previously described (Brimblecombe et al., 2015) using $200 \mu$ s stimulus pulses ( $0.6 \mathrm{~mA}$; Cragg, 2003). Stimuli of a range of durations and frequencies were used (single pulses, trains of five pulses at $5 \mathrm{~Hz}, 20$ pulses at 5 and $20 \mathrm{~Hz}$ ) to optimize detection of any modulation of $[\mathrm{DA}]_{\mathrm{o}}$ by SP. Electrical stimulations were repeated at $2.5 \mathrm{~min}$ intervals. Each stimulus type was repeated in triplicate in random order.

All data were obtained in the presence of the nAChR antagonist, dihydro- $\beta$ erythroidine (DH $\beta E, 1 \mu \mathrm{M}$ ) as previously described (Brimblecombe et al., 2015), to remove the confounding effects of cholinergic interneurons that regulate ACh release and subsequently DA (Rice and Cragg, 2004; Threlfell et al., 2012). Release was TTX-sensitive (data not shown) as previously described (Threlfell et al., 2010, 2012). Release was insensitive to a mixture of antagonists for glutamate and GABA receptors (bicuculline $10 \mu \mathrm{M}$, saclofen $50 \mu \mathrm{M}$, MCPG $200 \mu \mathrm{M}$, D-AP5 $50 \mu \mathrm{M}$, and GYKI $10 \mu \mathrm{M}$; data not shown) as previously described (Threlfell et al., 2010) and, furthermore, in pilot studies $(n=4)$ the presence of these blockers did not preclude a range of effects of SP on evoked $[\mathrm{DA}]_{\mathrm{o}}$ (from a $30 \%$ increase to a $50 \%$ decrease).

Immunochemistry and site identification. After recording, sites were marked and processed for MOR-ir. The CFM was replaced with a micropipette and $0.5-1.0 \mu \mathrm{l}$ of $1-\mu \mathrm{m}$-diameter FluoSpheres (Invitrogen) injected to indicate recording sites. Slices were fixed (either PFA or neutral buffered formalin $4 \%$ formaldehyde) for at least $3 \mathrm{~d}$, washed in PBS, re-sectioned to $40 \mu \mathrm{m}$, and incubated in $20 \%$ NGS (Jackson ImmunoResearch) in $0.3 \%$ Triton X-100 PBS (PBS-Tx) and 5\% fetal bovine serum for $4 \mathrm{~h}$. Sections were then incubated overnight at $4^{\circ} \mathrm{C}$ in primary antibody for MOR (1:1000 rabbit anti-MOR; Sigma) with 5\% NGS and 1\% fetal bovine serum. Sections were washed (PBS, $2 \times 0.3 \%$ PBS-Tx) and incubated for $2 \mathrm{~h}$ at room temperature in secondary antibody (1:1000
DyLight 594 goat anti-rabbit; Jackson ImmunoResearch) in PBS-Tx, 1\% NGS, and fetal bovine serum. After washes in PBS-Tx then PBS, sections were mounted on gelled slides with Vectashield (Vector Laboratories). Sections were imaged using an Olympus BX41 microscope with Q-Click cooled monochrome CCD camera (Olympus Medical). Monochrome images were converted to pseudocolored using QCapture Pro 7 and optimized using histogram equalization.

The attribution of recording sites to striosomes, border, or matrix was blind with respect to DA release data. Recording sites were identified through two alternative means to allow for error in FluoSphere placement, using sections containing the most dense FluoSpheres as representative of the area sampled by the CFM. First, recording site, R, was centered on the brightest point of FluoSpheres (asterisk) and defined as a circle of radius $25 \mu \mathrm{m}$ (Fig. $2 A$ ) from which a CFM likely samples DA within the time course of these signals (Cragg and Rice, 2004). Second, a larger recording site, $\mathrm{R}^{\prime}$, was defined as an oval of twice the minimum area necessary to contain all FluoSphere beads. The two estimates of the recording site did not differ in the subsequent attribution of any site to a given territory type; therefore, recordings sites were defined by R only for illustration purposes. The edges of patches of intense MOR-ir that indicate striosomes, S, were approximated using QCapture Pro 7 (Fig. 2A, area $S)$. The identities of the recording sites were classified as follows: "striosome" when circle R was completely contained within area S (Fig. $2 D)$; "boundary" when circle R contained matrix and striosome, i.e., circle $\mathrm{R}$ intersected the outline of area S (Fig. 2E); and as "matrix," M, when circle $\mathrm{R}$ was external to any area $\mathrm{S}$ (Fig. $2 F$ ).

Statistical analysis. Data are expressed as mean \pm SEM, where $n=$ number of experiments $=$ recording sites. Data at each site were averaged from at least three recordings for each stimulus, normalized to control for each site. Population means were compared using one-way or twoway ANOVA with post hoc Bonferroni's $t$ test where appropriate or repeated-measures $t$ test, using GraphPad Prism. Parametric tests were appropriate as raw control data passed Shapiro-Wilk normality test $(p=0.11)$.

Drugs. DH $\beta$ E was purchased from Tocris Bioscienceor Ascent Scientific and SP and L-732,138 were purchased from Abcam. All other reagents were purchased from Sigma Aldrich. $\mathrm{DH} \beta \mathrm{E}$ and SP were dissolved in $\mathrm{dH}_{2} \mathrm{O}$ and $\mathrm{L}-732,138$ in ethanol at $1000-2000 \times$ final concentrations and stored at $-20^{\circ} \mathrm{C}$. Drug concentrations were chosen in accordance with previous studies (Anderson et al., 1993; Kombian et al., 2003; Govindaiah et al., 2010). Furthermore, the concentration of SP used here (1 $\mu \mathrm{M})$ is within a range seen in vivo: extracellular striatal SP levels detected with microdialysis to date in rats can be calculated from published data (Nakamura et al., 2013) as being on the order of $0.1 \mu \mathrm{M}$ at baseline and increased by $\mathrm{K}^{+}$to $200-1600 \%$ (Ebner and Singewald, 2006; Nakamura et al., 2013).

\section{Results}

We monitored evoked [DA] o within dorsal striatum at sites selected blind with respect to striosome-matrix location. SP $(1 \mu \mathrm{M})$ had a range of outcomes on peak-evoked $[\mathrm{DA}]_{\mathrm{o}}$ ranging from a $100 \%$ increase to a $50 \%$ reduction depending on recording site $(n=33$ experiments; Fig. $1 A-D)$. The effects of SP on peak [DA $]_{\mathrm{o}}$ did not vary with different stimuli (Fig. 1D) and were neurokinin-1 receptor (NK1R)-specific as they were reversed by the NK1R antagonist L-732,138 $(10 \mu \mathrm{M})$. To indicate the population data without subclassifying response types using arbitrary criteria, we identified the direction-independent modulus of the effect of SP (the difference between observed $[D A]_{o}$ and the mean control $[D A]_{o}, \sqrt{\left([D A]-[D A]_{\text {control }}\right)^{2}}$ for $1 \mathrm{p}$ data. The mean modular effect of SP across recording sites was a $\sim 35 \%$ change to peak $[\mathrm{DA}]_{\mathrm{o}}$, which was reversed by L-732,138 (Fig. 1E; one-way ANOVA, $F_{(2,47)}=11.2 p<0.001$; Bonferroni post-tests: control vs SP, $p<0.001$; SP vs L-732,138 $p<0.01$; control vs L-732,138, $p>0.05)$.

We investigated whether the different effects of SP were due to location within the striosome-matrix axis. For 22 experiments, 
A Increase

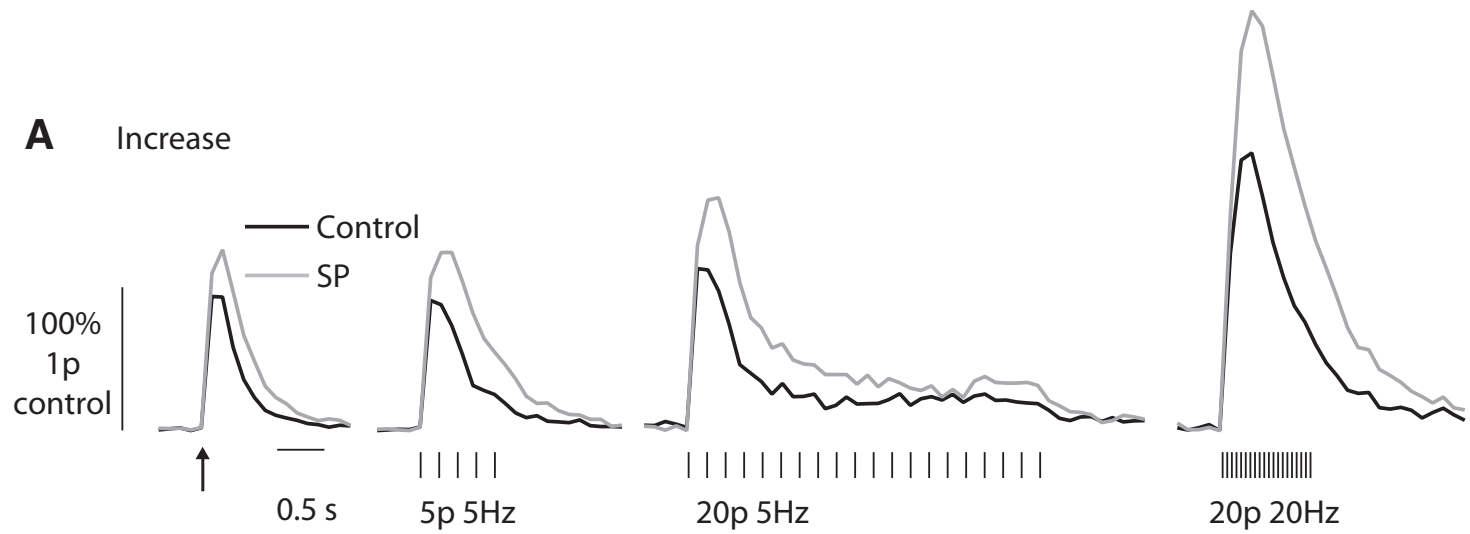

B Decrease
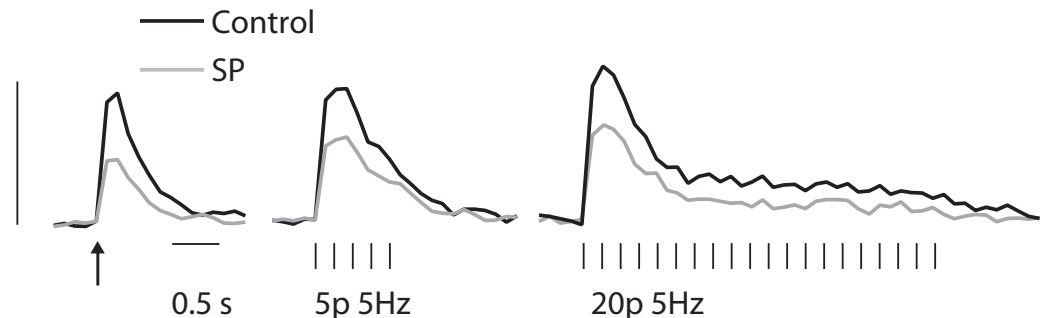

111111111111111111111

$20 \mathrm{p} 5 \mathrm{~Hz}$

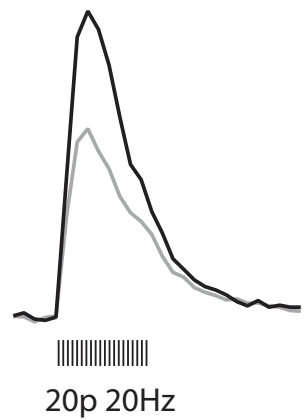

C No response
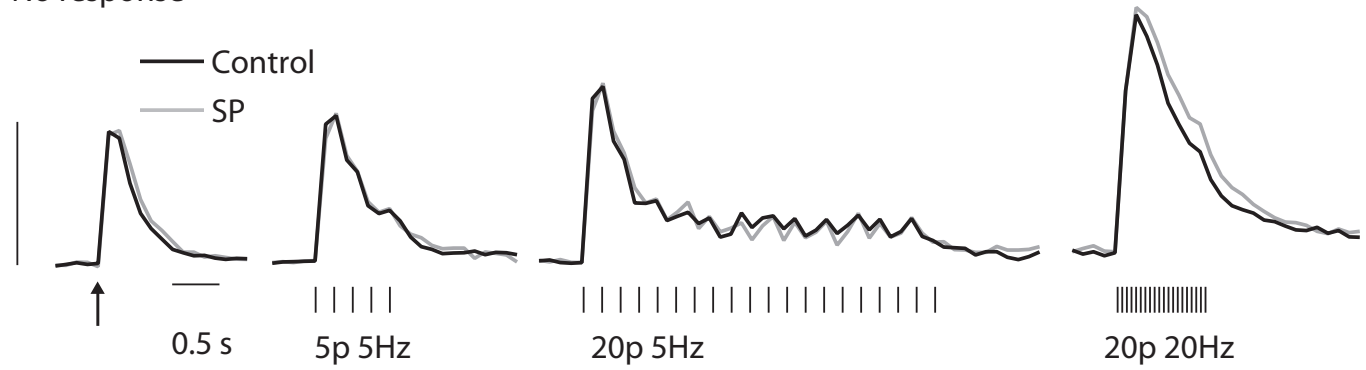

D
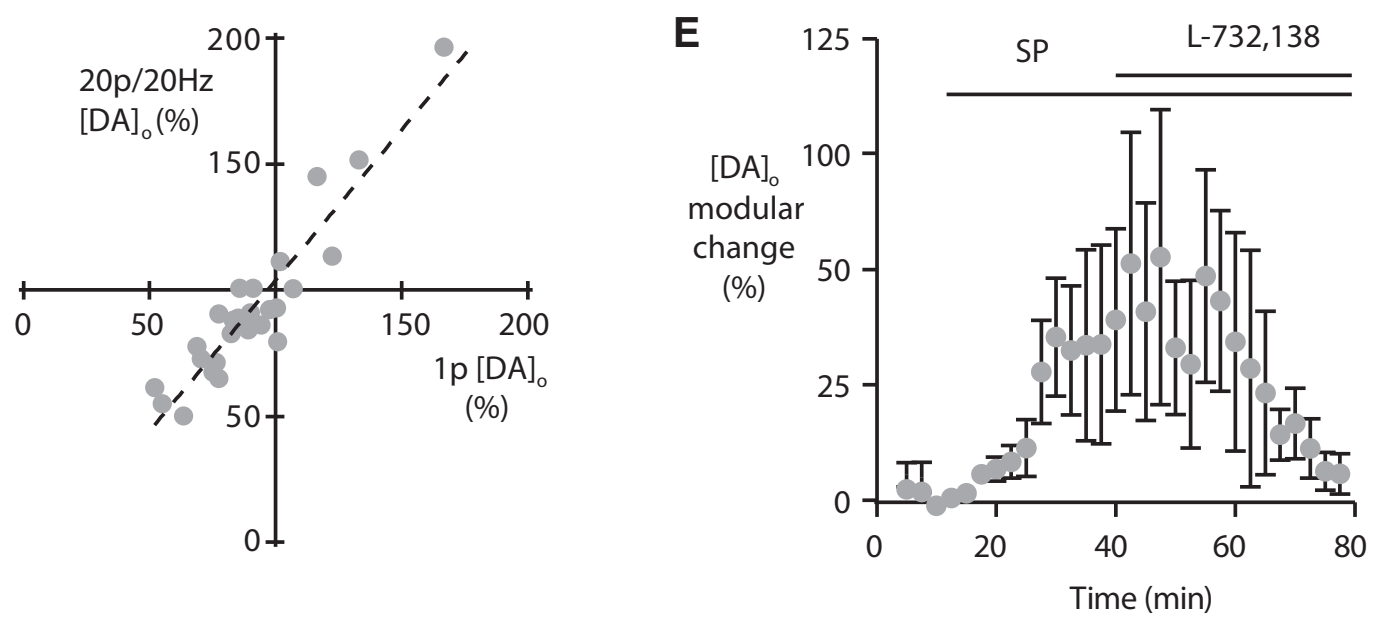

Figure 1. SP can increase, decrease, or have no effect on DA release. $\boldsymbol{A}-\boldsymbol{C}$, Example DA transients showing increased $(\boldsymbol{A})$, decreased $(\boldsymbol{B})$, or no effect $(\boldsymbol{C})$ on evoked $[D A]_{0}$. Data are normalized to $1 \mathrm{p}$-evoked $[\mathrm{DA}]_{0}$ in control conditions. $\boldsymbol{D}$, The range of effects of SP on peak $[\mathrm{DA}]_{0}$ (percentage of control) evoked by $20 \mathrm{p} / 20 \mathrm{~Hz}$ and $1 \mathrm{p}$ were linearly related: $R^{2}=0.86$, slope $=1.2$. $\boldsymbol{E}$, NK1R antagonist reverses the modular effect of $S P$ on $1 p$-evoked $[D A]_{0} ; N=33$. 


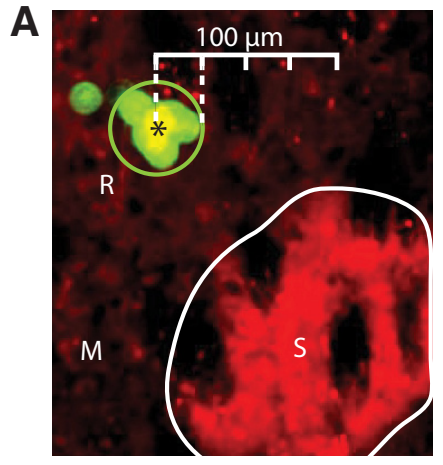

D Striosome

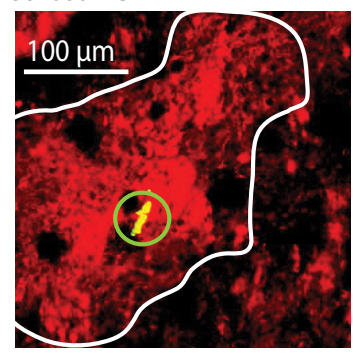

E Boundary

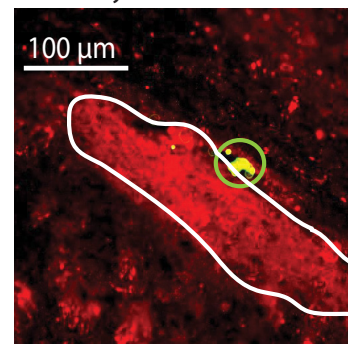

F Matrix

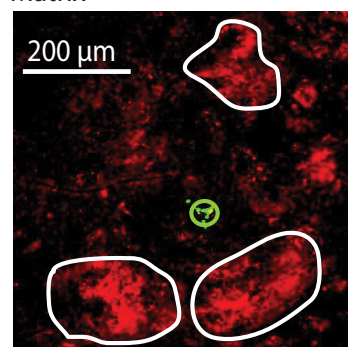

G

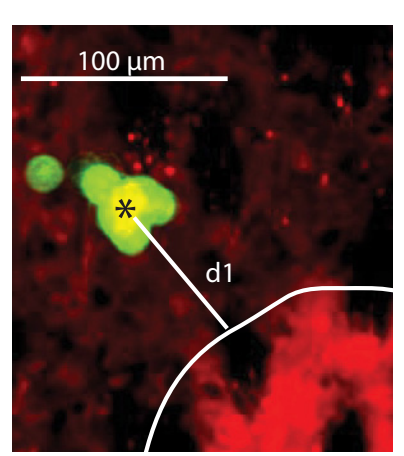

B

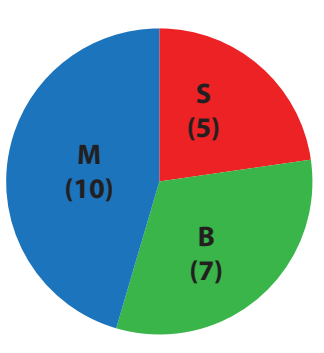

C
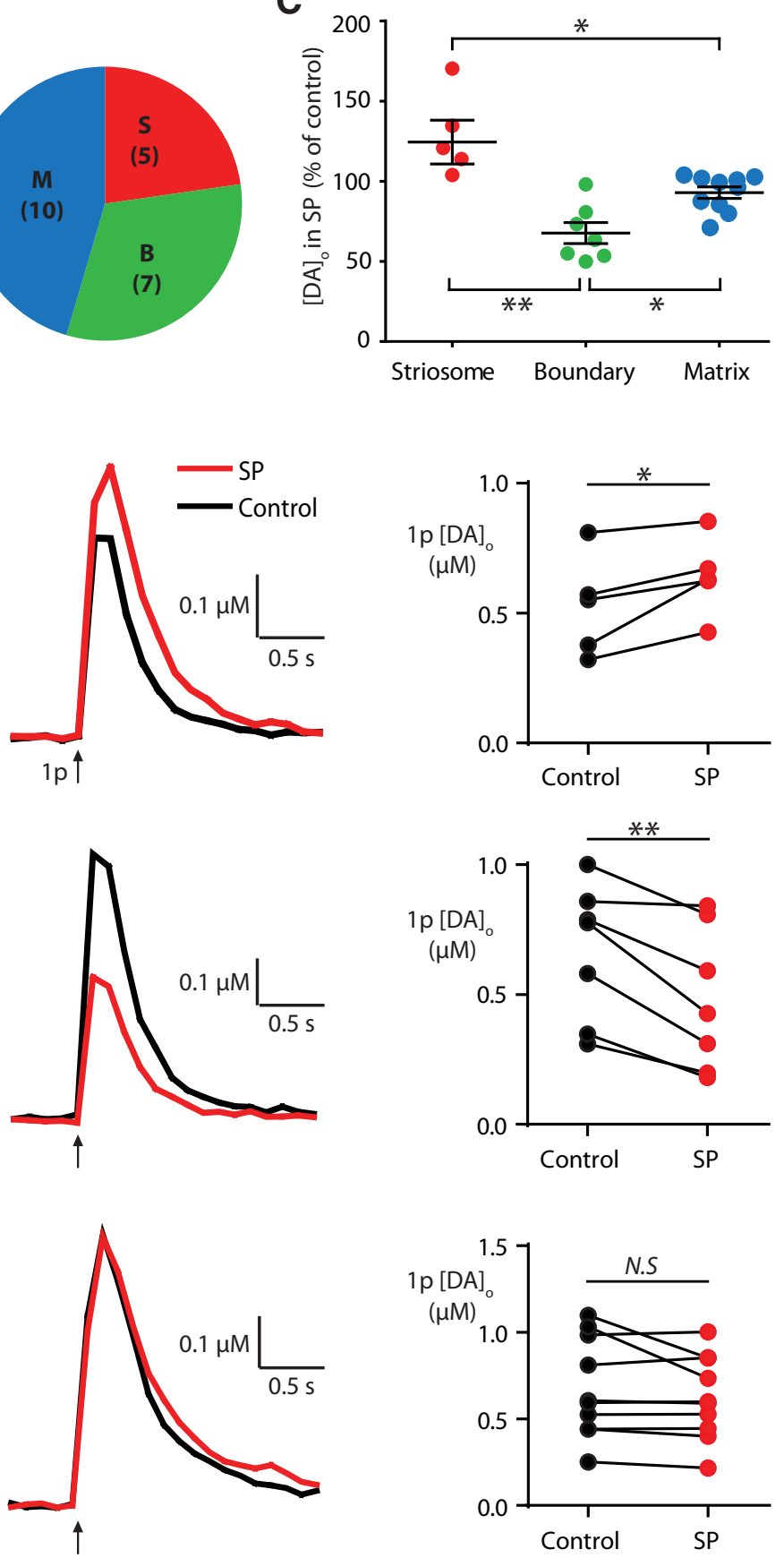

H

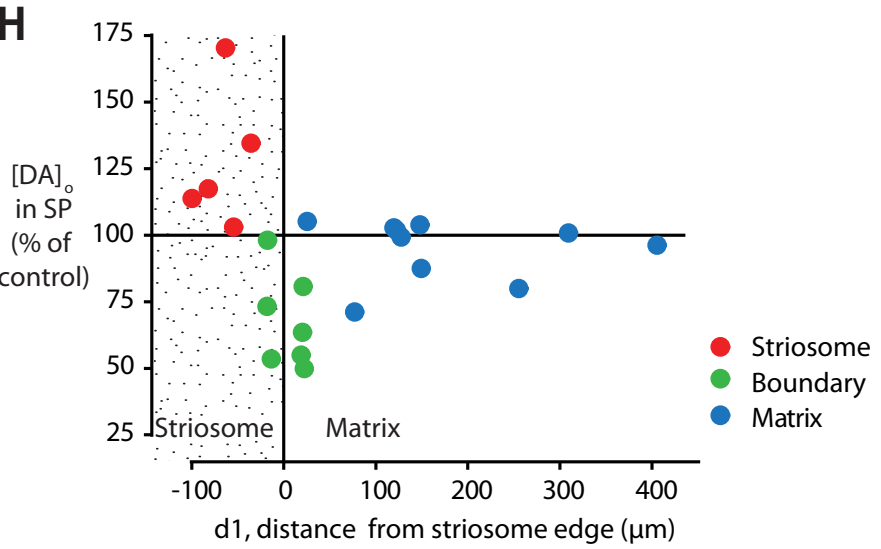



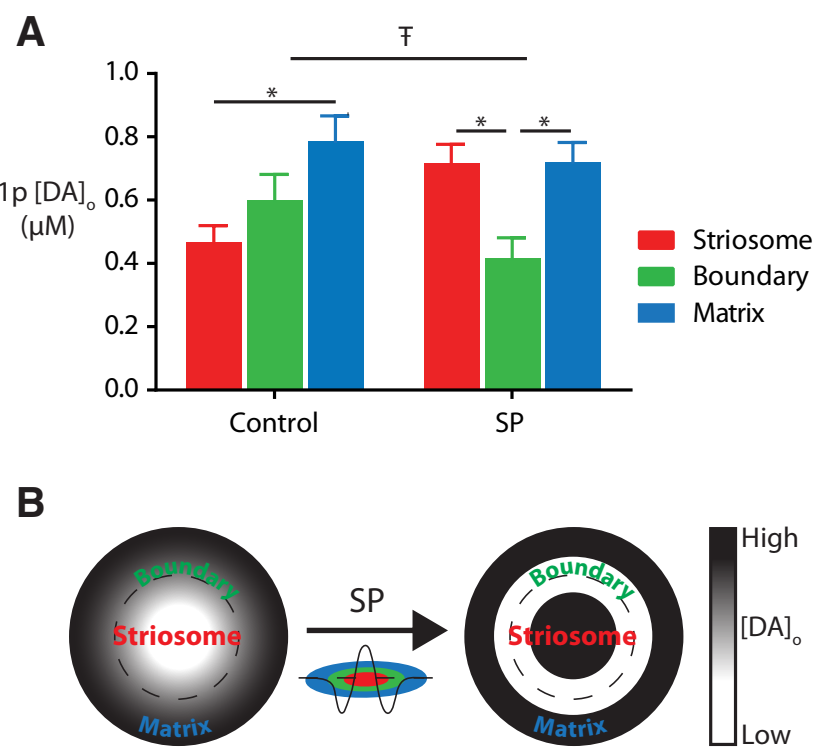

Figure 3. SP enhances center-surround contrast of striosomal DA signals. $A$, Mean peak $D A]_{0}$ evoked by $1 p$ in control or with SP in striosomes (red), boundary (green), and matrix (blue). $[D A]_{0}$ varies significantly between compartments, before and after SP. Two-way ANOVA, Bonferroni post-test $(n=6),{ }^{*} p<0.05$. $\mp$, Interaction between compartment and SP effect: $F_{(2,38)}$ $=9.9, p<0.01 . B, 2 D$ schematic depiction of the relative contrast in $[D A]_{0}$ in each territory before (left) and after SP (right), showing relatively high DA (black) to low DA (white). Center, Arrow indicates transformation of [DA] $]_{0}$ by SP (from data shown in Fig. 2).

recording sites $(\mathrm{R})$ were marked by injection of FluoSphere beads, and slices covisualized for MOR-ir indicating striosomes (S; Fig. 2A). Sites were classified as either striosomal ( $S$; $n=5 / 22$ sites (23\%); Figure $2 B, D)$, boundary $[n=7 / 22$ (32\%); Fig. $2 B, E]$, or matrix $(\mathrm{M}, n=10 / 22(45 \%)$; Fig. $2 B, F)$. When the effects of SP on $[D A]_{0}$ were grouped accordingly, they varied significantly with territory (Fig. $2 C$; one-way $\operatorname{ANOVA~} F_{(2,19)}=$ 13.4, $p<0.001$; Bonferroni post-tests: striosome vs matrix and matrix vs boundary, $p<0.05$, striosome vs boundary $p<0.01$ ). Within striosomes, SP increased [DA] ovoked by $1 \mathrm{p}$ by $30 \pm$ $10 \%$ (Fig. 2C,D; $t$ test with repeated-measures $t_{(4)}=3.7, p<$ 0.05 ). In boundaries, SP reduced evoked $[\mathrm{DA}]_{\mathrm{o}}$ by $30 \pm 6 \%$ (Fig. $\left.2 C, E ; t_{(6)}=4.6, p<0.01\right)$ whereas in matrix, SP had no significant effect (Fig. $2 C, F ;-6 \pm 3 \%, t_{(9)}=1.5$ ). In addition to this ternary qualitative means of classifying recording sites, the effects of SP were also compared with the quantitative distance (d1) from the brightest FluoSphere point (asterisk) to the nearest striosomal edge (Fig. $2 G$ ). This approach revealed a biphasic relationship between the effect of SP on evoked $[\mathrm{DA}]_{\mathrm{o}}$ and location within the striosome-matrix axis (Fig. $2 \mathrm{H}$ ) with the polarity of the effect varying most between central striosomal regions and a surrounding boundary band of $\sim 50$ $\mu \mathrm{m}$ width.

\section{$\leftarrow$}

Figure 2. Effect of $S P$ varies between striosomal, boundary. and matrix. $A$, Classification of recording sites, $R$; MOR-rich striosomes, $S$ (red); and matrix, M. Circle $R$, radius $=25 \mu \mathrm{m}$ is centered on brightest FluoSphere label (*). Scale bar, $100 \mu \mathrm{m}$. B, Proportional representation of sites in each territory. $C$, The effect of SP on evoked [DA] $]_{0}$ (percentage of control 1p). One-way ANOVA, Bonferroni post-tests. $\boldsymbol{D}-\boldsymbol{F}$, Left, representative examples of recording sites in striosome (D), boundary (E), and matrix (F). Scale bars: $\boldsymbol{C}, \boldsymbol{D}, 100 \mu \mathrm{m} ; \boldsymbol{E}, 200 \mu \mathrm{m}$. Center, Typical DA transients evoked by $1 p$ in control conditions (black) and with SP (red). Right, Peak-evoked $[D A]_{0}$ in control (black) vs $S P\left(\right.$ red); $t$ test with repeated measures, ${ }^{*} p<0.05$ and ${ }^{* *} p<0.01$; NS, not significant $\boldsymbol{G}$, Distance, d1, from nearest striosome edge. $\boldsymbol{H}$, Effect of SP on evoked [DA] (percentage of control) versus d1. Colors indicate ternary site classification used in $\boldsymbol{B}-\boldsymbol{F}$.
To understand better the impact of SP on the weighting of striosomal-matrix DA signals, we used these data to compare how SP changed the levels of $[\mathrm{DA}]_{\mathrm{o}}$ evoked in each territory relative to another. SP significantly changed the relative levels in $[D A]_{0}$ seen between compartments (Fig. 3A; two-way ANOVA interaction $\mathrm{SP} \times$ compartment, $\left.F_{(2,38)}=9.9, p<0.01\right)$. In the absence of SP, evoked [DA] o was apparently lowest in striosomes (1p stimulus; Fig. $3 A$, left; Bonferroni post-tests: striosomes vs matrix: $p<0.05)$. In the presence of SP, when striosomal $[\mathrm{DA}]_{\mathrm{o}}$ was increased and boundary $[\mathrm{DA}]_{\mathrm{o}}$ decreased, $[\mathrm{DA}]_{\mathrm{o}}$ was significantly lower in boundary than either striosome or matrix regions (Fig. 3A, right; Bonferroni post-tests: $p<0.05$ ), but comparable in striosomes and matrix. These observations reveal in particular that SP modifies the contrast in DA signals between striosomes and surrounding territories, particularly boosting striosomal DA signals at the expense of boundary (Fig. 3B).

\section{Discussion}

Here, we reveal that SP differently modulates DA release in striosomes versus striosomal boundaries and matrix. SP acting through NK1Rs can boost DA release within the centers of striosomes, but diminish DA release in a border region where striosomes and matrix interface, suggesting that SP weights striosomal DA signals in a center-surround manner. These findings also provide support for a functional delineation of a peristriosomal area, for which there is some anatomical evidence, in addition to striosomal versus matrix compartments, which might play an underappreciated role in striatal signal integration.

The effects of SP on striatal DA transmission have long been reported as varied, ranging from facilitation to inhibition (Starr, 1982; Petit and Glowinski, 1986; Boix et al., 1992; Guzman et al., 1993). Here, we reveal that both the facilitatory and inhibitory actions of SP on DA are mediated via NK1Rs, and are governed by location within the striosome-matrix axis. These findings are somewhat consistent with earlier work showing that lesioning NK1 receptors in the striatum led to loss of differential striosome-matrix postsynaptic responses to dopaminergic treatment (Saka et al., 2002).

The mechanisms underlying opposing outcomes on DA mediated through NK1Rs are unresolved. DA neurons express NK1R (Lessard and Pickel, 2005), although whether there is NK1R trafficking to axons with differential targeting to striosomes and matrix has not yet been shown to our knowledge. Axonal "bushes" of individual DA neurons do appear to respect striosome-matrix boundaries (Matsuda et al., 2009), providing potential scope for striosome matrix-specific expression of receptors and other mechanisms on DA axons. Furthermore, while NK1Rs are primarily $G_{q}$-coupled, they can also couple to $G_{i}$ and $\mathrm{G}_{\mathrm{s}}$ (Quartara and Maggi, 1997; Roush and Kwatra, 1998), leading to a range of secondary messengers and divergent effects (Quartara and Maggi, 1997; Lai et al., 2008). In addition, NK1Rs form heteromeric complexes with other metabotropic receptors (Pfeiffer et al., 2003), including the MOR, which is expressed at highest levels in striosomes. MOR and NK1R interact functionally in striatum (Pérez et al., 2007), expression levels of NK1R are affected by MOR activation and vice versa (Pfeiffer et al., 2003; Yu et al., 2009; Pal et al., 2013) and, intriguingly, NK1R KO in mice prevents addiction to opioids (Murtra et al., 2000). Therefore, the effect of NK1R activation might depend upon the expression of other signaling pathways that vary within the striosomal-matrix axis. ChI regulation of DA should not be a factor here as nAChRs were inhibited, and GABA receptors that might be activated by cross-border collaterals of MSNs, or GABAergic interneurons, do 
not regulate DA release during these short stimulus trains (Threlfell et al., 2010), but it remains possible that the effects of SP are indirect, e.g., governed by NK1R-rich somatostatin/NOS/NPYpositive interneurons ( $\mathrm{Li}$ et al., 2002) that might be tonically active in the slice (Beatty et al., 2012). How these neurons might influence DA transmission is incompletely defined, however.

These data also provide support for a functionally distinct peristriosomal boundary area, a third zone in addition to striosomes and matrix. A peristriosomal "annulus" or "striocapsule" has been identified anatomically as rich in Met-enk (Faull et al., 1989; Goto et al., 2013), or having SP and NK1R-overlap (Jakab et al., 1996), and is thought to be enriched in some interneurons (Graybiel et al., 1986; Kubota and Kawaguchi, 1993). The inhibition of DA transmission by SP seen here in a restricted boundary region of $\sim 50 \mu \mathrm{m}$ width at the interface of striosome and matrix resembles these zones, and might confer distinct consequences on striatal signal processing. For example, SP appears to weight DA signals in striosomes at the expense of those in boundaries, and to enhance the contrast between striosomal and boundary DA. Modeling studies have proposed that limbic and motor information from segregated striatal inputs might be assimilated into an output signal (from MSNs) by information transfer from striosomes to matrix within modules via interneurons at the striosomal-matrix interface (Amemori et al., 2011). Changes to dopamine could strongly govern any such "communication" between striosomes and matrix via DA receptor-rich interneurons.

In conclusion, we have identified discrete modulation of DA transmission within the striosomal-matrix axis by $\mathrm{SP}$, which weights DA signals in striosomes, but inhibits those at striosomal-matrix interface. These data support distinct roles for striosomes, peristriosomal, and matrix regions that could impact significantly on signal processing within striatum. Studies of striatal function should endeavor to consider the roles of these compartments, for which the development of genetically encoded markers of striosomes (Davis and Puhl, 2011) or matrix (Lopez-Huerta et al., 2015) could provide useful tools.

\section{References}

Amemori K, Gibb LG, Graybiel AM (2011) Shifting responsibly: the importance of striatal modularity to reinforcement learning in uncertain environments. Front Hum Neurosci 5:47. CrossRef Medline

Anderson JJ, Chase TN, Engber TM (1993) Substance P increases release of acetylcholine in the dorsal striatum of freely moving rats. Brain Res 623: 189-194. CrossRef Medline

Beatty JA, Sullivan MA, Morikawa H, Wilson CJ (2012) Complex autonomous firing patterns of striatal low-threshold spike interneurons. J Neurophysiol 108:771-781. CrossRef Medline

Blomeley CP, Kehoe LA, Bracci E (2009) Substance P mediates excitatory interactions between striatal projection neurons. J Neurosci 29:49534963. CrossRef Medline

Boix F, Huston JP, Schwarting RK (1992) The C-terminal fragment of substance $\mathrm{P}$ enhances dopamine release in nucleus accumbens but not in neostriatum in freely moving rats. Brain Res 592:181-186. CrossRef Medline

Bolam JP, Izzo PN, Graybiel AM (1988) Cellular substrate of the histochemically defined striosome/matrix system of the caudate nucleus: a combined Golgi and immunocytochemical study in cat and ferret. Neuroscience 24:853-875. CrossRef Medline

Brimblecombe KR, Gracie CJ, Platt NJ, Cragg SJ (2015) Gating of dopamine transmission by calcium and axonal N, Q, T and L-type voltage-gated calcium channels differs between striatal domains. J Physiol 593:929-946. CrossRef Medline

Cragg SJ (2003) Variable dopamine release probability and short-term plasticity between functional domains of the primate striatum. J Neurosci 23:4378-4385. Medline

Cragg SJ, Rice ME (2004) DAncing past the DAT at a DA synapse. Trends Neurosci 27:270-277. CrossRef Medline
Crittenden JR, Graybiel AM (2011) Basal ganglia disorders associated with imbalances in the striatal striosome and matrix compartments. Front Neuroanat 5:59. CrossRef Medline

Davis MI, Puhl HL 3rd (2011) Nr4a1-eGFP is a marker of striosome-matrix architecture, development and activity in the extended striatum. PLoS One 6:e16619. CrossRef Medline

Desban M, Kemel ML, Glowinski J, Gauchy C (1993) Spatial organization of patch and matrix compartments in the rat striatum. Neuroscience 57: 661-671. CrossRef Medline

Ebner K, Singewald N (2006) The role of substance P in stress and anxiety responses. Amino Acids 31:251-272. CrossRef Medline

Faull RL, Dragunow M, Villiger JW (1989) The distribution of neurotensin receptors and acetylcholinesterase in the human caudate nucleus: evidence for the existence of a third neurochemical compartment. Brain Res 488:381-386. CrossRef Medline

Fujiyama F, Sohn J, Nakano T, Furuta T, Nakamura KC, Matsuda W, Kaneko T (2011) Exclusive and common targets of neostriatofugal projections of rat striosome neurons: a single neuron-tracing study using a viral vector. Eur J Neurosci 33:668-677. CrossRef Medline

Gerfen CR (1984) The neostriatal mosaic: compartmentalization of corticostriatal input and striatonigral output systems. Nature 311:461-464. CrossRef Medline

Gerfen CR (1992) The neostriatal mosaic: multiple levels of compartmental organization in the basal ganglia. Annu Rev Neurosci 15:285-320. CrossRef Medline

Gerfen CR, Baimbridge KG, Miller JJ (1985) The neostriatal mosaic: compartmental distribution of calcium-binding protein and parvalbumin in the basal ganglia of the rat and monkey. Proc Natl Acad Sci U S A 82: 8780-8784. CrossRef Medline

Gerfen CR, Herkenham M, Thibault J (1987) The neostriatal mosaic: II. Patch- and matrix-directed mesostriatal dopaminergic and nondopaminergic systems. J Neurosci 7:3915-3934. Medline

Goto S, Kawarai T, Morigaki R, Okita S, Koizumi H, Nagahiro S, Munoz EL, Lee LV, Kaji R (2013) Defects in the striatal neuropeptide Y system in X-linked dystonia-parkinsonism. Brain 136:1555-1567. CrossRef Medline

Govindaiah G, Wang Y, Cox CL (2010) Substance P selectively modulates GABA(A) receptor-mediated synaptic transmission in striatal cholinergic interneurons. Neuropharmacology 58:413-422. CrossRef Medline

Graybiel AM, Ragsdale CW Jr (1978) Histochemically distinct compartments in the striatum of human, monkeys, and cat demonstrated by acetylthiocholinesterase staining. Proc Natl Acad Sci U S A 75:57235726. CrossRef Medline

Graybiel AM, Ragsdale CW Jr, Yoneoka ES, Elde RP (1981) An immunohistochemical study of enkephalins and other neuropeptides in the striatum of the cat with evidence that the opiate peptides are arranged to form mosaic patterns in register with the striosomal compartments visible by acetylcholinesterase stainin. Neuroscience 6:377-397. CrossRef Medline

Graybiel AM, Baughman RW, Eckenstein F (1986) Cholinergic neuropil of the striatum observes striosomal boundaries. Nature 323:625-627. CrossRef Medline

Guzman RG, Kendrick KM, Emson PC (1993) Effect of substance P on acetylcholine and dopamine release in the rat striatum: a microdialysis study. Brain Res 622:147-154. CrossRef Medline

Gygi SP, Gibb JW, Johnson M, Hanson GR (1993) Blockade of tachykinin NK1 receptors by CP-96345 enhances dopamine release and the striatal dopamine effects of methamphetamine in rats. Eur J Pharmacol 250:177180. CrossRef Medline

Holt DJ, Graybiel AM, Saper CB (1997) Neurochemical architecture of the human striatum. J Comp Neurol 384:1-25. CrossRef Medline

Jakab RL, Hazrati LN, Goldman-Rakic P (1996) Distribution and neurochemical character of substance $\mathrm{P}$ receptor (SPR)-immunoreactive striatal neurons of the macaque monkey: accumulation of SP fibers and SPR neurons and dendrites in "striocapsules" encircling striosomes. J Comp Neurol 369:137-149. CrossRef Medline

Johnston JG, Gerfen CR, Haber SN, van der Kooy D (1990) Mechanisms of striatal pattern formation: conservation of mammalian compartmentalization. Brain Res Dev Brain Res 57:93-102. CrossRef Medline

Kombian SB, Ananthalakshmi KV, Parvathy SS, Matowe WC (2003) Substance $\mathrm{P}$ depresses excitatory synaptic transmission in the nucleus accumbens through dopaminergic and purinergic mechanisms. J Neurophysiol 89:728-737. CrossRef Medline

Kubota Y, Kawaguchi Y (1993) Spatial distributions of chemically identified 
intrinsic neurons in relation to patch and matrix compartments of rat neostriatum. J Comp Neurol 332:499-513. CrossRef Medline

Lai JP, Cnaan A, Zhao H, Douglas SD (2008) Detection of full-length and truncated neurokinin-1 receptor mRNA expression in human brain regions. J Neurosci Methods 168:127-133. CrossRef Medline

Lessard A, Pickel VM (2005) Subcellular distribution and plasticity of neurokinin-1 receptors in the rat substantia nigra and ventral tegmental area. Neuroscience 135:1309-1323. CrossRef Medline

Li JL, Kaneko T, Mizuno N (2002) Synaptic association of dopaminergic axon terminals and neurokinin-1 receptor-expressing intrinsic neurons in the striatum of the rat. Neurosci Lett 324:9-12. CrossRef Medline

Lopez-Huerta VG, Nakano Y, Bausenwein J, Jaidar O, Lazarus M, Cherassse Y, Garcia-Munoz M, Arbuthnott G (2015) The neostriatum: two entities, one structure? Brain Struct Funct. Advance online publication. Retrieved Feb 6, 2015. doi:10.1007/s00429-015-1000-4.

Matsuda W, Furuta T, Nakamura KC, Hioki H, Fujiyama F, Arai R, Kaneko T (2009) Single nigrostriatal dopaminergic neurons form widely spread and highly dense axonal arborizations in the neostriatum. J Neurosci 29:444-453. CrossRef Medline

Miura M, Saino-Saito S, Masuda M, Kobayashi K, Aosaki T (2007) Compartment-specific modulation of GABAergic synaptic transmission by mu-opioid receptor in the mouse striatum with green fluorescent protein-expressing dopamine islands. J Neurosci 27:9721-9728. CrossRef Medline

Murtra P, Sheasby AM, Hunt SP, De Felipe C (2000) Rewarding effects of opiates are absent in mice lacking the receptor for substance P. Nature 405:180-183. CrossRef Medline

Nakamura Y, Izumi H, Shimizu T, Hisaoka-Nakashima K, Morioka N, Nakata Y (2013) Volume transmission of substance P in striatum induced by intraplantar formalin injection attenuates nociceptive responses via activation of the neurokinin 1 receptor. J Pharmacol Sci 121:257-271. CrossRef Medline

Pal K, Mathur M, Kumar P, DeFea K (2013) Divergent $\beta$-arrestindependent signaling events are dependent upon sequences within G-protein-coupled receptor C termini. J Biol Chem 288:3265-3274. CrossRef Medline

Pérez S, Tierney A, Deniau JM, Kemel ML (2007) Tachykinin regulation of cholinergic transmission in the limbic/prefrontal territory of the rat dorsal striatum: implication of new neurokinine 1-sensitive receptor binding site and interaction with enkephalin/mu opioid receptor transmission. J Neurochem 103:2153-2163. CrossRef Medline
Petit F, Glowinski J (1986) Stimulatory effect of substance P on the spontaneous release of newly synthesized $[3 \mathrm{H}]$ dopamine from rat striatal slices: a tetrodotoxin-sensitive process. Neuropharmacology 25:1015-1021. CrossRef Medline

Pfeiffer M, Kirscht S, Stumm R, Koch T, Wu D, Laugsch M, Schröder H, Höllt V, Schulz S (2003) Heterodimerization of substance P and mu-opioid receptors regulates receptor trafficking and resensitization. J Biol Chem 278:51630-51637. CrossRef Medline

Quartara L, Maggi CA (1997) The tachykinin NK1 receptor. Part I: ligands and mechanisms of cellular activation. Neuropeptides 31:537-563. CrossRef Medline

Rice ME, Cragg SJ (2004) Nicotine amplifies reward-related dopamine signals in striatum. Nat Neurosci 7:583-584. CrossRef Medline

Roush ED, Kwatra MM (1998) Human substance P receptor expressed in Chinese hamster ovary cells directly activates $\mathrm{G} \alpha \mathrm{q} / 11, \mathrm{G} \alpha \mathrm{s}$, and $\mathrm{G} \alpha \mathrm{o}$. FEBS Lett 428:291-294. CrossRef Medline

Saka E, Iadarola M, Fitzgerald DJ, Graybiel AM (2002) Local circuit neurons in the striatum regulate neural and behavioral responses to dopaminergic stimulation. Proc Natl Acad Sci U S A 99:9004-9009. CrossRef Medline

Starr MS (1982) Influence of peptides on 3H-dopamine release from superfused rat striatal slices. Neurochem Int 4:233-240. CrossRef Medline

Threlfell S, Clements MA, Khodai T, Pienaar IS, Exley R, Wess J, Cragg SJ (2010) Striatal muscarinic receptors promote activity dependence of dopamine transmission via distinct receptor subtypes on cholinergic interneurons in ventral versus dorsal striatum. J Neurosci 30:3398-3408. CrossRef Medline

Threlfell S, Lalic T, Platt NJ, Jennings KA, Deisseroth K, Cragg SJ (2012) Striatal dopamine release is triggered by synchronized activity in cholinergic interneurons. Neuron 75:58-64. CrossRef Medline

Tremblay L, Kemel ML, Desban M, Gauchy C, Glowinski J (1992) Distinct presynaptic control of dopamine release in striosomal- and matrixenriched areas of the rat striatum by selective agonists of NK1, NK2, and NK3 tachykinin receptors. Proc Natl Acad Sci U S A 89:11214-11218. CrossRef Medline

Watabe-Uchida M, Zhu L, Ogawa SK, Vamanrao A, Uchida N (2012) Whole-brain mapping of direct inputs to midbrain dopamine neurons. Neuron 74:858-873. CrossRef Medline

Yu YJ, Arttamangkul S, Evans CJ, Williams JT, von Zastrow M (2009) Neurokinin 1 receptors regulate morphine-induced endocytosis and desensitization of mu-opioid receptors in CNS neurons. J Neurosci 29:222-233. CrossRef Medline 